\title{
41.2. LOWER CRETACEOUS LIMESTONES FROM THE HELLENIC TROUGH, IONIAN BASIN (SITE 127)
}

\author{
Wolf Maync, Geological Consulting Service, Muri (Berne), Switzerland
}

\section{INTRODUCTION}

Three holes $\left(127,127 \mathrm{~A}, 127 \mathrm{~B}\right.$; latitude $35^{\circ} 43.95^{\prime} \mathrm{N}$, longitude $22^{\circ} 29.67^{\prime}$.E) were drilled west of Crete in the Hellenic Trough during Leg 13 of the Deep Sea Drilling Project. These holes were placed near the north-eastern inner wall (arc side) of a partially filled oceanic trench which rims the Hellenic Island Arc in the eastern Mediterranean (Figure 1). All three holes in the Hellenic Trough bottomed in Lower Cretaceous limestones. The mode of emplacement of the Lower Cretaceous limestones-which apparently occur as blocks-in the trench setting is not clear, and interpretations have been controversial. Two hypotheses have been presented (see Chapter 9 of this volume): a) they represent a tectonic "melange" resulting from recent underthrusting of the Ionian Basin beneath the Hellenic Arc; b) they are exotic blocks (olistostrome) on a continental talus slope. The writer tends to accept the second alternative because a layer of Pliocene nannofossil ooze, $70 \mathrm{~cm}$ thick, was found to be intercalated between two hard rock sections ( 427 to $435.3 \mathrm{~m}$ and 436 to $437 \mathrm{~m}$ ) in Hole 127. This ooze interbed also carries fragments of dolomite and limestone. Middle Pliocene foraminiferal nannofossil ooze (Discoaster surculus Zone) was again recovered in Core 19 taken at the bottom of Hole 127; that is, below the lowermost Lower Cretaceous blocks drilled here. Moreover, some of the Lower Cretaceous limestone fragments recovered in Core 1 of Hole 127B are embedded in an indurated matrix of greenish-gray pelagic OrbulinaGlobigerina marl of probable Pliocene age.

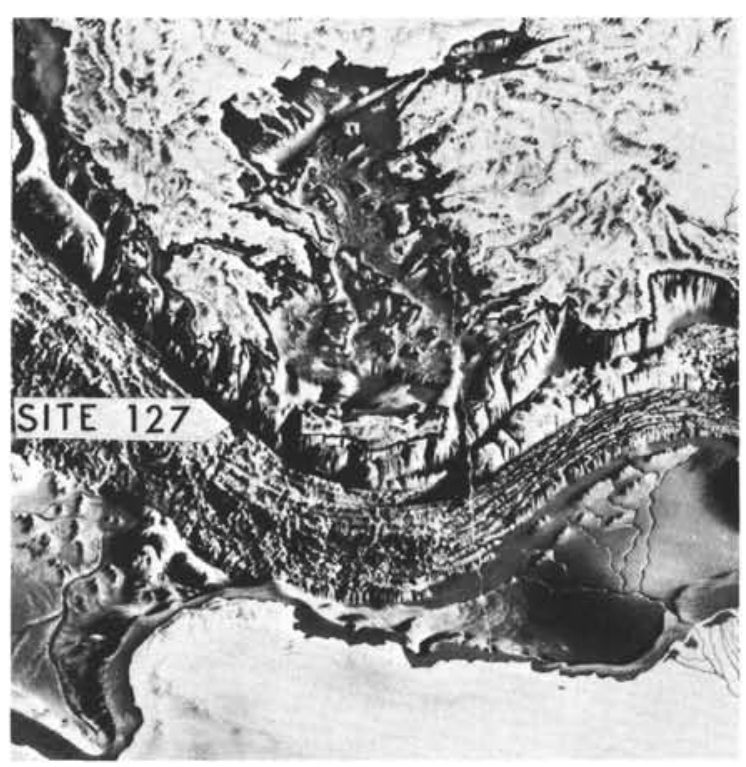

Figure 1. Location of Site 127 in the Hellenic Trench west of Crete.

\section{LITHOLOGY AND FAUNAL CONTENT OF THE LOWER CRETACEOUS LIMESTONES}

\section{Hole 127}

The hard rock section below the Pleistocene trench fill, composed of Lower Cretaceous dolomite and limestone, was first encountered in Core 16 (428.7 to $429 \mathrm{~m}$ below bottom). Two pieces of barren dark gray to brownish fractured dolomite, coarsely recrystallized, were recovered (Plate 1, Figure 1).

Core 17 ( 434.3 to $435 \mathrm{~m}$ below the sea floor) yielded nine pieces of hard rock. Piece $1(0$ to $68 \mathrm{~cm})$ is a partly brecciated, mylonitized limestone with strongly recrystallized portions and stylolitic sutures. Except for one questionable specimen of Ammobaculites, no fossils were observed.

Piece 2 is a micritic limestone, parts of which are completely dolomitized and/or recrystallized, and which contains calcite veins (Plate 1, Figure 2) and some obscure indeterminable fragments of foraminifera.

Piece 3 is a mylonitic-brecciated, in part dolomitic micrite with stylolitic sutures and calcite veins; some random sections of Orbitolina ${ }^{1}$ (Plate 1, Figure 3) were observed. Orbitolina and Chrysalidina were recognized in piece 8 (Plate 1, Figures 4-6).

Core 18 (434.9 to $436 \mathrm{~m})$ yielded four fragments of partly dolomitized limestone, next to olive-gray, plastic nannofossil ooze with Sphaeroidinellopsis seminulina (Schwager), S. subdehiscens (Blow), Globorotalia acostaensis Blow, etc. (det. M. B. Cita) of Middle Pliocene age. This ooze also contains small scattered fragments of dolomite and limestone.

Piece 1, a micritic limestone (partly dolomitized) with calcite veins, contains specimens of Orbitolina, Chrysalidina, Haplophragmoides?, indeterminable sections of foraminifera, and Hensonella cylindrica Elliot.

Piece $4(41$ to $64 \mathrm{~cm})$, a dark-gray to brownish, partly brecciated micrite, contains Orbitolina, Chrysalidina, Haplophragmoides?, Sabaudia minuta (Hofker), Cuneolina cf. laurentii Sart. and Cres., Valvulammina aff. picardi Henson Ophtalmidiidae, Miliolidae, and algae such as Hensonella cyclindrica Elliot and Bačinella irregularis Radoičić (Plate 2, Figures 1-6; Plate 3, Figures 1-4).

\footnotetext{
${ }^{1}$ In our shipboard report, we referred all the random sections to Orbitolina gr. discoidea-conoidea Gras (=0.lenticularia (Blumenbach) fide Hofker, =subgenerotype of Palorbitolina Schroeder, 1963), known from the Barremian-Aptian-Albian. A closer determination is not ventured as none of the thin-sections prepared on board the Glomar Challenger cut the embryonic apparatus. This opinion is shared by Prof. R. Schroeder, Frankfurt, an expert in orbitolinids, to whom some thin-sections were submitted. He also pointed out (in litt.) the primitive evolutionary stage as well as the thin marginal zone of the concerned specimens which are suggestive of Urgonian (Barremian-Aptian) age.
} 
INNER WALL

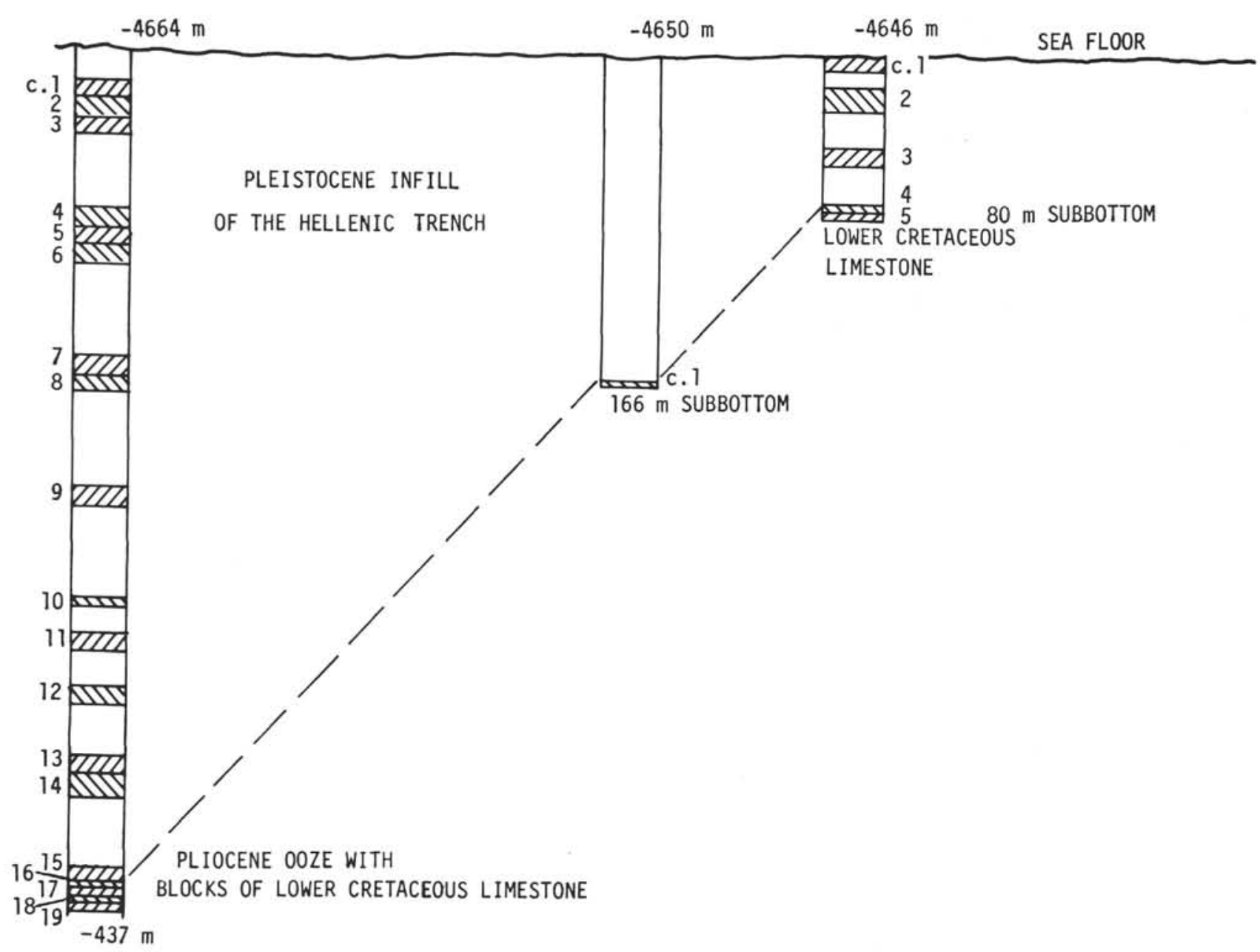

Figure 2. Position of cores taken in the three holes at Site 127, SW of Kythera Island, Hellenic Trench.

Core 19 ( 436.4 to $437 \mathrm{~m}$ below bottom) consists of 0.6 $\mathrm{m}$ of marl ooze and eight fragments of dolomite and fractured, recrystallized limestone.

\section{Hole 127A}

Hole $127 \mathrm{~A}$ was drilled on the inner wall of the Hellenic Trough. This hole penetrated Quaternary marl ooze, rich in planktonic foraminifera, pteropods and coccoliths, down to a depth of 79 meters below the sea floor where it encountered the first block of light gray, micritic limestone (Core 4, at $79 \mathrm{~m}$ ). This limestone bears Orbitolina, Chrysalidina, Nezzazata gr. simplex Omara, Sabaudia minuta (Hofker), Cuneolina cf. laurentii Sart. \& Cresc., Valvulammina aff. picardi Henson, Haplophragmoides?, Miliolidae, Ophtalimidiidae, Textulariidae, Hensonella cylindrica Elliot, Bačvinella irregularis Radoičcić, and a Codiacean alga (Boueina?; Plate 4, Figure 1) (Plate 4, Figures 1-4; Plate 5, Figure 1).

Core $5(120$ to $150 \mathrm{~cm})$, from 79.7 to $80 \mathrm{~m}$, yielded five fragments of a light gray to brownish fractured biomicrite which contains Orbitolina, Chrysalidina, Sabaudia minuta (Hofker), Nezzazata gr. simplex Omara, Valvulammina aff. picardi Henson, Haplophragmoides?, Cuneolina cf. laurentii Sart. \& Cresc., Miliolidae, Ophtalmidiidae, etc. (Plate 5, Figures 2-5; Plate 6, Figures 1-6).

\section{Hole 127B}

The last hole of Site 127 was located between Holes 127 and $127 \mathrm{~A}$; one core was taken at a subbottom depth of 166 meters.

Core $1(110$ to $150 \mathrm{~cm})$ is represented by seven pieces of limestone and breccia (angular limestone fragments embedded in a foraminiferal marl matrix). Piece 1, a pebble of brecciated biomicrite in a greenish-gray OrbulinaGlobigerina marl, contains Valvulammina aff. picardi Henson (Plate 7, Figure 2) and some indeterminable smaller foraminifera.

The strongly brecciated micrite with dolomitized parts (piece 2) contains rare discoid specimens of Orbitolina and 
rare algal debris of Pianella turgida Radoičić. Piece 3 reveals angular components of dolomitic, partly brecciated limestone of different lithology with indeterminable sections of smaller foraminifera (Plate 8 , Figure 4). Piece 5, a dark gray to brown limestone of the same lithology as piece 1 , contains Cuneolina $\mathrm{cf}$. laurentii Sart. \& Cresc., Valvulammina, Nezzazata?, Miliolidae, etc. Piece 6, a gray-brown fractured limestone with stylolitic sutures, embedded in Orbulina-Globigerina ooze, is nonfossiliferous. Some rare Ophtalmidiidae were observed in the fractured, partly dolomitized limestone of piece 7 .

\section{REMARKS ON THE AGE OF THE LOWER CRETACEOUS BLOCKS}

The available material from the Lower Cretaceous cores recovered at Site 127 is not sufficient for the preparation of a large number of thin-sections. For this reason, unambiguous determinations of the represented microfossils, and hence a more precise age assignment, cannot be made.

The presence of Hensonella cylindrica in Holes 127 (Core 18) and 127A (Core 4) strongly suggests, however, a Barremian-Aptian age which is also favored by Orbitolina (Palorbitolina).

\section{Orbitolina}

(Plate 1, Figures 3, 5-6; Plate 4, Figure 2; Plate 5, Figures 1-3; Plate 6, Figures 3-6; Plate 8, Figures 1-3)

It was pointed out that all the specimens of Orbitolina encountered in the thin-sectioned limestone blocks, comparable to $O$. discoidea-conoidea $\mathrm{Gras}=$ Orbitolina lenticularis (Blumenbach), are suggestive of a Barremian-Aptian to Lower Albian age.

Some authors consider the Orbitolina lenticularis Zone as basal Middle Cretaceous (central Italy). It falls between the Cuneolina camposaurii Zone and the Cuneolina pavonia parva Zone (Albian-Cenomanian) (Crescenti, Crostella, Donzelli \& Raffi, 1969).

According to Crescenti (1969), the Cuneolina camposaurii Zone with Sabaudia minuta, Cuneolina laurentii, Cuneolina scarsellai, Nezzazata simplex, Bačinella irregularis, etc., is Valanginian-Aptian in age, the Orbitolina lenticularis Zone marks the Aptian-Albian boundary, and the Cuneolina pavonia parva Zone with Cuneolina laurentii, Cuneolina scarsellai, Nezzazata simplex, Ovalveolina, Bačnella irregularis, Pianella turgida, etc, is Albian-Cenomanian.

In addition to Orbitolina, the thin-sections prepared on board the Glomar Challenger contain:

Chrysalidina

Cuneolina cf. laurentii Sartoni and Crescenti

Sabaudia minuta (Hofker)

Nezzazata gr. simplex Omara

Valvulammina aff. picardi Henson

Haplophragmoides?

The algae are represented by:

Hensonella cylindrica Elliot

Bačinella irregularis Radoičić

Pianella turgida Radoičić

and Boueina?.
Chrysalidina

(Plate 1, Figure 4; Plate 3, Figures 1-3; Plate 4, Figures 1, 3; Plate 5, Figure 1)

The specific identification is questionable. As no labyrinthic axial column is revealed in our thin-sections, an attribution to Pseudochrysalidina (=Dukhania Henson) is not justified.

Our forms correspond to those figured as Verneuilinidae (Eggerellina?) from the Barremian-Aptian of Yugoslavia (Radoičić, 1960).

Similar forms already occur in the Jurassic. No stratigraphic significance can hence be given to the specimens encountered in the thin-sections from Holes 127 and 127A.

Cuneolina cf. laurentii Sartoni \& Crescenti (Plate 2, Figures 1-2; Plate 5, Figures 2-3)

The small tests of Cuneolina found in some of the thin-sections seem to belong to Cuneolina laurentii, rather than to Cuneolina scarsellai De Castro. ${ }^{2}$

Cuneolina laurentii is a species recorded from the Cuneolina camposaurii Zone (Valanginian-Aptian) of Southern Italy (Sartoni \& Crescenti, 1962; Sinni, 1966a, 1966b), which, however, was also found in the lower part (Albian) of the next higher biozone of Cuneolina pavonia parva (Sartoni \& Colalongo, 1964; De Castro, 1964).

In the central part of the Apennines (Pescara-Gran Sasso), the Lower Cretaceous Cuneolina camposaurii Zone is defined as the stratigraphic interval between the Upper Jurassic (Malm) and the Orbitolina level (=base of the Albian-Cenomanian Cuneolina pavonia parva Zone) (Crescenti, Crostella, Donzelli \& Raffi, 1969; Crescenti, 1969).

The range of Cuneolina laurentii is given as Barremian to Lower Albian (Chiocchini \& Di Napoli, 1966).

\section{Sabaudia minuta (Hofker)}

(Plate 2, Figures 1, 3?, 4; Plate 5, Figure 5)

This small species originally assigned to the genus Textulariella is based on material from the Aptian-Albian Orbitolina beds of north and northeast Spain (Hofker, 1965) where it is associated with Orbitolina lenticularis, Simplorbitolina manasi, Mayncella greigi, Daxia cenomana, and others.

Sabaudia minuta is also recorded from the Upper Aptian of the southern Apennines in association with Orbitolina, Cuneolina scarsellai, Cuneolina laurentii, Bačinella irregularis, etc. (Chiocchini \& Di Napoli, 1966).

Sabaudia minuta, which also occurs in France, Switzerland, etc., may be taken as an index species of the Barremian-Lower Albian (Hostettler, 1968).

\footnotetext{
${ }^{2}$ Dr. Piero De Castro, Naples, the author of Cuneolina scarsellai, kindly gave me his opinion concerning the specific determination of some of the Cuneolinae from Site 127.
} 
Nezzazata gr. simplex Omara

(Plate 4, Figure 1; Plate 6, Figure 1)

The genus Nezzazata was created for the peculiar, asymmetric-trochospiral, later planispiral tests assigned to the Barkerinidae which occur in Cenomanian strata of Egypt (Omara, 1956). The genus Begia Smout is a junior synonym.

Nezzazata simplex Omara is a widespread and characteristic microfaunal element of Cenomanian beds (Egypt, Lebanon, Israel, Iran, Iraq, Yugoslavia, Greece, Italy) which was subsequently also encountered in strata of the Lower Turtonian (Israel, Iraq) as well as in Labian and Aptian sediments (Israel, Italy). Its stratigraphic range was recently extended to the Hauterivian and Senonian (Hamamoui \& Saint-Marc, 1970); consequently, Nezzazata cannot play an important role in an age assignment.

Valvulammina aff. picardi Henson

(Plate 3, Figures 1, 4; Plate 5, Figure 4;

Plate 6, Figure 2; Plate 7, Figure 2)

Valvulammina of the picardi type widely occurs in the Upper Cretaceous. The type species Valvulammina picardi was established for specimens derived from Santonian beds of Egypt (Henson, 1948).

Forms comparable to Valvulammina picardi were later described and figured from the Cenomanian and Albian of Israel, Lebanon, Iran, Yugoslavia and Italy (Reiss, 1961; Bozorgnia, 1964; Radoicic, 1965; Hamamoui, 1966; Hamamoui \& Saint-Marc, 1970).

A form most similar to the one from Site 127 was also illustrated from the Cuneolina camposaurii Zone (Valanginian-Aptian) of southern Italy (Sartoni \& Crescenti, 1962).

\section{Haplophragmoides? sp.}

(Plate 2, Figure 1)

Some of the available thin-sections are. tentatively interpreted as a small multi-chambered Haplophragmoides. An attribution to Nautiloculina might also be considered.

Identical tests have been figured as Haplophragmoides sp. from the Cuneolina camposaurii Zone (Valanginian-Aptian) as well as from the Upper Aptian-Lower Albian of southern Italy (Sartoni \& Crescenti, 1962; Sinni, 1966a).

\section{Algae}

Hensonella cylindrica Elliot

\section{(Plate 2, Figures 5, 6; Plate 4, Figure 4)}

The dasycladacean alga Hensonella cylindrica was based on material from Barremian-Aptian sediments of Iraq and Iran (Elliot, 1960).

Hensonella cyclindrica subsequently proved to be a very useful stratigraphical index of the Barremian-Aptian, as it has not been found so far in post-Aptian beds. It occurs, for example, in the Aptian of Israel and in the BarremianAptian of Iran (Reiss, 1961; Bozorgnia, 1964; James \& Wynd, 1965).

The author observed Hensonella cylindrica in the Lower Cretaceous blocks drilled in Holes 127 and $127 \mathrm{~A}$, but this characteristic form is not represented in the Cretaceous limestones encountered in Hole 127B.

\section{Bačinella irregularis Radoičić \\ (Plate 4, Figure 1)}

This nodular incrusted form of alga incerta sedis formed by irregular cells of different shape and size was described from Barremian-Aptian limestones of Yugoslavia, where it occurs in association with other algae and Orbitolina (Radoičić, 1959).

Further occurrences in the Yugoslavian Dinarids and in the Apennines of Italy were subsequently discovered (Radoičcić, 1960; Sartoni \& Crescenti, 1962; Farinacci \& Radoičic, 1964; 1966; Sinni, 1966; Crescenti, 1969); Bacinella irregularis was found in the zone with Orbitolina conoideadiscoidea/lenticularis (Barremian-Albian) and in the zone of Cuneolina camposaurii (Valanginian-Aptian) to Lower Albian).

Bacinella irregularis also occurs in the Urgonian limestone facies (Upper Barremian-Lower Aptian) of Sicily, where it is associated with Orbitolina lenticularis, Dictyoconus, Iraqia, Cuneolina camposaurii, etc., (Montanari, 1964).

In the Abruzzi Mountains, central Italy, Bacinella irregularis is present in the Orbitolina lenticularis Zone of largely Albian age (Crescenti, Crostella, Donzelli \& Raffi, 1969; Crescenti, 1969).

The main stratigraphic range of Bacinella irregularis in southern Italy is Upper Aptian to Lower Albian (Chiocchini \& Di Napoli, 1966).

Bacinella irregularis is also reported from Aptian and post-Neocomian breccias of the Carnian Alps of northern Italy, in association with Orbitolina texana parva Douglass (Cousin, Durand Delga \& Sigal, 1966) as well as from a Valanginian algal limestone of Ibiza, Balearic Islands (Colom, 1969).

Pianella turgida Radoixić

This dasycladacean alga, characterized by its large thallus from which branches extend in alternating rows, was first described and figured from the Cenomanian of Yugoslavia (Radoičić, 1965).

Pianella turgida was later reported from Albian-Cenomanian beds of Italy (Sinni, 1966; Crescenti, 1969).

One tangential section of Pianella turgida was recognized in Core 1 of Hole 127B.

\section{ON THE OCCURRENCE OF ORBITOLINA-BEARING BEDS IN GREECE}

The regional structural framework of the western and central Hellenides (according to published sources) and the location of Site 127 are shown in Figure 3.

Orbitolina limestones have a wide distribution in Greece, (Ionian zone, Gavrovo-Tripolitza zone, Olonos-Pindos nappe, Parnassos-Trapezona nappe, Vardar zone, etc.), but no details or modern determinations are available ${ }^{3}$.

The major part of the numerous localities from which Orbitolina is recorded is assigned to the Cenomanian. This

\footnotetext{
${ }^{3}$ Professor Jean Aubouin, Paris, and Professor George Marinos, University of Athens, very kindly answered my inquiring letters pertinent to the geology of Greece for which I wish to express my sincere thanks.
} 


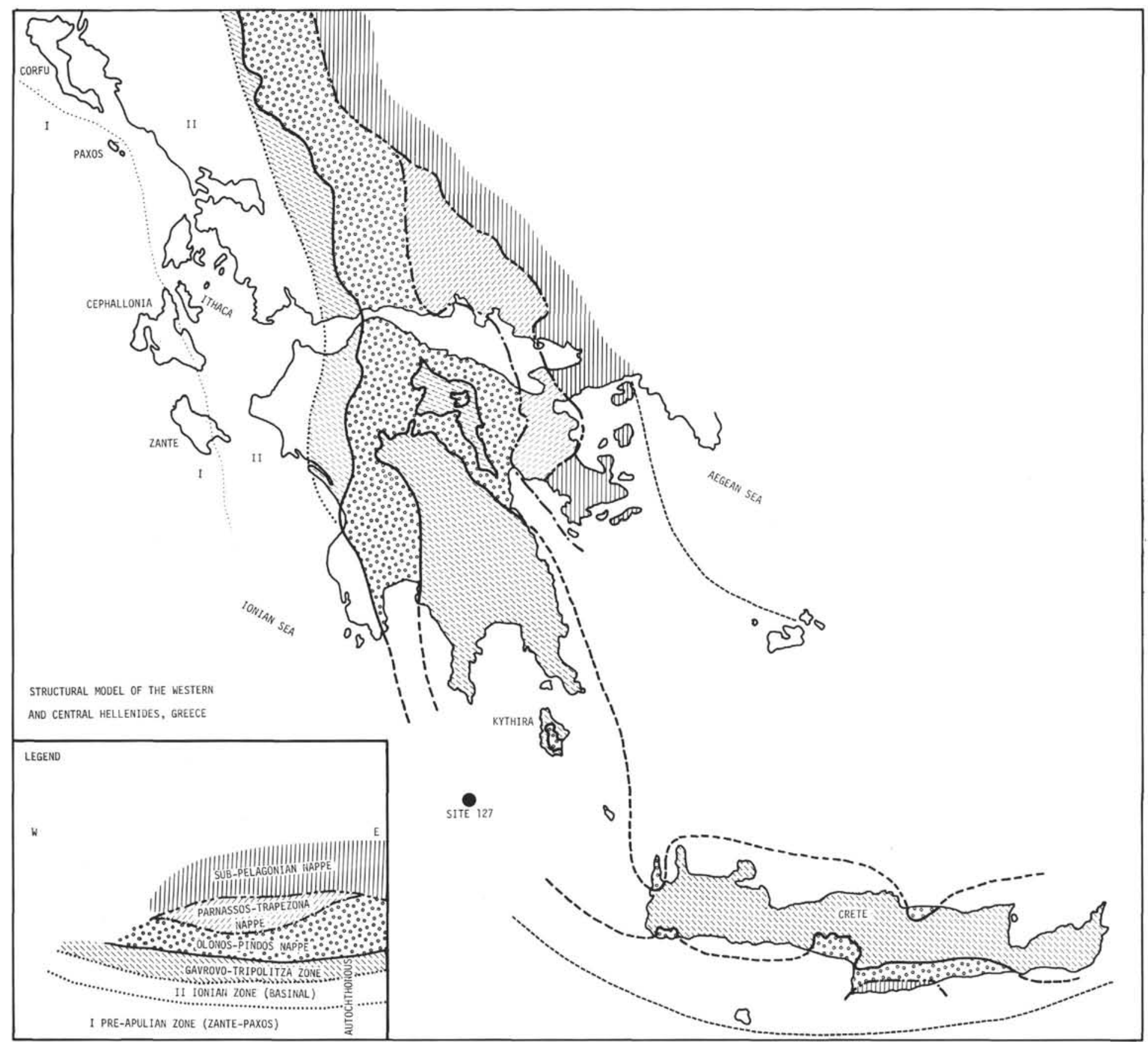

Figure 3. Structural Model of the western and central Hellenides, Greece. 
interval is characterized by Orbitolina concava (Lam.) and Orbitolina conica (D'Arch.), typically Cenomanian species (the former sets in with the Albian). Locally, for example, in the Viglaes Limestone of the Ionian zone, the intermediate Orbitolina interval also contains Rotalipora appenninica (Renz), another Cenomanian index species.

In addition to Orbitolina concava and Orbitolina conica of Cenomanian age, several other species are listed in the relevant literature, for example, Orbitolina lenticularis (Blumenbach), Orbitolina conoidea-discoidea Gras, Orbitolina bulgarica (Boue'), and others. ${ }^{4}$ These forms largely occur in a lower Orbitolina level and are suggestive of an Urgonian (Upper Barremian-Aptian) age.

The presence of a lower, pre-Cenomanian Orbitolina level (Barremian-Albian) was stressed in several papers by Carl Renz.

From the Viglaes Limestone of the Ionian zone, a pelagic chert-bearing thin-bedded limestone of about 450 meters thickness (Jurassic to Senonian), Urgonian Orbitolina and Trocholina alpina (Leupold) are recorded from the section below the Cenomanian (Renz \& Reichel, 1946).

The Tripolitza Limestone of the Gavrovo-Tripolitza zone, a complex of dark limestones up to 1000 meters in thickness of Upper Triassic age at the base and with a Middle Eocene Alveolina-Nummulites fauna at the top, shows above the Cladocoropsis-Clypeina limestone (Upper Jurassic) dark gray to black neritic limestones, more or less dolomitic, which carry Orbitolina, Trocholina, etc. With regard to their lithology, these limestones closely correspond to those drilled at Site 127 in the Hellenic Trough.

The Cenomanian Orbitolina level is widely represented in the Mesozoic series of the Olonos-Pindos nappe, which is thrust on the Gavrovo-Tripolitza Flysch (see Figure 3) and can be traced from Albania southward across the Pindos Range, Peloponnesos, Kythera Island to Crete (see Figure 3). The bioclastic limestones which yield Orbitolina are usually gray-reddish, well-bedded, and contain shale breaks and chert. The presence of Orbitolina conoidea, $O$. bulgarica, and $O$. paronai suggests that pre-Cenomanian strata are also developed.

In the Tsoumerka Mountains of the Pindos Range, a complex of radiolarites, 250 to 300 meters in thickness, and brecciated Trocholina limestone (upper Jurassic to basal Cretaceous) is overlain by 50 meters of flysch-like beds; that is, an alternation of sandstones, marls, limestones, radiolarites, from which Orbitolina lenticularis, Orbitolina trochus (Fritsch), Orbitolina bulgarica, and Dictyoconus arabicus Henson of Barremian-Aptian age are reported (Aubouin, et al, 1960).

Brecciated limestones with Orbitolina conoidea and rudistids are mentioned from Kythera Island where they overlie the shale-radiolarite group of the Pindos nappe.

\footnotetext{
${ }^{4}$ According to J. Hofker (1963), the genus Orbitolina is monotypical and all the described species belong to Orbitolina lenticularis of which the form-groups I-V are differentiated by means of certain features of the megalospheric embryonic apparatus. The classification by R. Schroeder (1963, etc.) places i.a. Orbitolina bulgarica, $O$. conoidea-discoidea, in synonymy with Orbitolina lenticularis for which the subgenus Palorbitolina was created. This group embraces the earliest known representatives of the genus Orbitolina (Upper Barremian to base of the Upper Aptian).
}

Dark, thick-bedded, partly dolomitic limestones with chert in the region of Ethia, southern Crete, contain Orbitolina conoidea and Orbitolina paronai which point to a pre-Cenomanian Orbitolina level.

Overthrust on the Pindos Flysch (Danian-Paleocene) or immediately on the Gavrovo-Tripolitza series is the Parnassos-Trapezona nappe of eastern Greece (see Figure 3). Here, pink-gray limestones with Orbitolina concava and Orbitolina conica occur widely. The Orbitolina limestones are developed here as compact, nonbrecciated limestonesas in the Ionian zone and the Olonos-Pindos nappe-and are attributed to the Cenomanian. However, they seem locally, for example, in the Oeta Mountains, to be of Urgonian age as they are reported to carry Orbitolina conoidea (Renz, 1955). A limestone breccia with Orbitolina, Iraqia, Dictyoconus, Cuneolina, etc., (Urgonian) was found to succeed Lower Cretaceous limestones containing Bacinella irregularis Rad., Pseudocyclammina, Trocholina in the southernmost Parnassos-Trapezona zone, eastern Peloponnesos (Dercourt, 1962). Transgressive limestones in the same area (Akros) which have yielded Orbitolina concava, Orbitolina discoidea, Trocholina arabica Henson, Nezzazata simplex Omara, Pseudolituonella reicheli Marie, etc. are assigned to the Cenomanian.

Orbitolina conoidea, $O$. paronai and $O$. bulgarica also occur in Lower Cretaceous oolitic limestones with corals of the Parnassos area.

Detrital black limestones with Orbitolina lenticularis, $O$. trochus, $O$. discoidea, etc. of Urgonian age have also been described from the Vardar zone of eastern Greece where they transgress on folded Upper Jurassic strata. The Cenomanian level with Orbitolina concava was found higher up in the section (Mercier, 1960).

Similar Urgonian Orbitolina-bearing limestones are known from the sub-Pelagonian nappe (Aubouin et al., 1960).

\section{REFERENCES}

Aubouin, J. et al., 1960. Le Cretace superieur on Grèce. Bull. Soc. Geol. France. 7e ser., Vol. II, No. 4. , 1963. Esquisse de la Géologie de la Grèce. Mem. Soc. Géol. France, Livre mém. Prof. Paul Fallot. Vol. II. Aubouin, J. and Dercourt, J., 1965. Sur la géologie de l'Egée: regard sur la Crète (Grèce). Bull. Soc. Géol. France. $7 \mathrm{e}$ sér., Vol. VII.

Aubouin, J. et al., 1965. Un élément externe de la zone du Pinde: la série d'Ethia (Crète, Grèce). Bull. Soc. Géol. France. $7 \mathrm{e}$ sér., Vol. VII.

642 .

Bozorgnia, F., 1964. Microfacies and microorganisms of Paleozoic through Tertiary sediments of some parts of Iran. Nat. Iranian Oil Co., Tehran.

Brunn, J. H., 1960. Les zones helléniques internes et leur extension. Réflexions sur l'orogenèse alpine. Bull. Soc. Géol.. France. 7e sér., Vol. II, No. 4.

Castro, De P., 1963. Nuove osservazioni sul livello ad Orbitolina in Campania. Boll. Soc. dei Naturalisti in Napoli. Vol. LXXI-1962.

, 1964. Cuneolina scarsellai $\mathrm{n}$. sp. nel Cretacico dell'A ppennino meridionale. Boll. Soc. dei Naturalisti in Napoli. Vol. LXXII-1963. 
, 1966. Contributo alla conoscenza delle alveoline albiano-cenomaniane della Campania. Boll. Soc. dei Naturalisti in Napoli. Vol. LXXV-1966.

Chiocchini M. and Di Napoli Alliata, E., 1966. Sulla presenza de "Textulariella minuta" Hofker e "Textulariella auruncensis" n. sp. (Foraminiferida) nel Cretacico inferiore dei Monti Aurunci (Lazio meridionale). Boll. Serv. Geol. d'Italia. Vol. LXXXVII-1966.

Colom, G. D., 1969. Litomicrofacies de los terrenos secundarios de España Mem. Real. Acad. Ciencias y Artes Barcelona. Vol. XXXIX, No. 11.

Cousin, M., Durand Delga, M. and Sigal, J., 1966. Données nouvelles sur le Crétacé de la haute et moyenne vallee du Tagliamento (Alpes méridionales, Frioul, Italie). Bull. Soc. Géol. France. 7e sér., Vol. VIII.

Crescenti, U., 1969. Biostratigrafia delle facies Mesozoiche dell'Appennino centrale: Correlazioni. Geol. Romana. Vol. VIII.

Crescenti, U., Crostella, A., Donzelli, G. and Raffi, G., 1969. Stratigrafia della serie calcarea dal Lias al Miocene nella regione Marchigiano-Abruzzese. Mem. Soc. Geol. Ital. Vol. VIII.

Dercourt, J., 1960. Esquisse géologique du Nord du P'eloponese. Bull. Soc. Géol. France. 7e sér., Vol. II.

- 1962. Contribution à l'etude géologique du Péloponèse. Terminaison paléogéographique du hautfond du Parnasse. Bull. Soc. Géol. France. Vol. IV, No. 3 .

Elliot. G. F., 1960. Fossil calcareous algal floras of the Middle East with a note on a Cretaceous Problematicum Hensonella cylindrica gen. et sp. nov. Quart. J. Geol. Soc., London. Vol. CXV.

Farinacci, A. and Radoičic, R., 1964. Correlazione fra serie giuresi et cretacee dell'Appennino centrale e delle Dinaridi esterne. Consiglio Naz. delle Ricerche, Rendiconti $A$. Vol. 7, No. 2. ser. 2.

Grader, P, and Reiss, Z., 1958. On the Lower Cretaceous of the Heletz area. Geol. Survey, Bull. No. 16, Oil Div. Paper No. 3.

Hamamoui, M., 1966. Microfossils from Cenomanian sections in the Negev. Israel Geol. Survey Rept. No. $\mathrm{Pal} / 3 / 66$.

Hamamoui, M. and Saint-Marc, P., 1970. Microfaunes et microfaciés du Cénomanien du Proche-Orient. Bull. Centre Rech. Pau-SNPA. Vol. 4, No. 2.

Henson, F. R. S., 1948. New Trochamminidae and Verneuilinidae from the Middle East. Ann. and Magaz. of Nat. Hist. ser. II, Vol. XIV (1947).

Hofker, J., Jr., 1965. Some foraminifera from the AptianAlbian passage of northern Spain. Leidse Geol. Mededel. pt. 33.

Hostettler, M., 1968. Étude sur des Sabaudia minuta (Hofker) (Foraminiféres) du nord de l'Espagne et du sud de la France. Diplome Études Supérieures. No. 64, Université de Dijon, Laboratoire de Géologie.

James, G. A. and Wynd, J. G., 1965. Stratigraphic nomenclature of Iranian Oil Consortium agreement area. Bull Am. Assoc. Petrol. Geol. Vol. 49, No. 12.

Mercier, J., 1959. Remarques sur la bordure occidentale de la zone du Vardar en Macédoine. C. R. somm. Soc. Géol. France. No. 8.

, 1960. Zone pélagonienne et zone du Vardar en Macédoine grècque. Bull. Soc. Géol. France. 7e ser., Vol. II.

Montanari, L., 1964. Geologia del Monte Pellegrino (Palermo). Rivista Mineraria Siciliana. Anno XV, No. 88-90.
Omara, S., 1956. New foraminifera from the Cenomanian of Sinai, Egypt.J. of Paleontol. Vol. 30. No. 4.

Papastamatiou, J., 1960. La géologie de la région montagneuse du Parnasse-Kiona-Oeta. Bull. Soc. Géol. France. 7 e ser., Vol. II, No. 4.

Radoičć, R., 1959. Some problematic microfossils from the Dinarian Cretaceous. Bull. Serv. Geol. and Geophys. Serbie. Vol. XVII.

1960. Microfaciès du Crétacé et du Paléogène des Dinarides externes de Yougoslavie. Inst. Recherches Géol. R. P. Crna Gora, Pal. Din. Yougosl. ser. A: Micropal., Vol. IV, No. I.

1965. Pianella turgida n. sp. from the Cenomanian of the Outer Dinarids, Geol. Vjesnik Inst. Geol. Istrazivanja Zagreb. Svezak 18, broj 1.

1968. Biostratigrafija povlatne serije bijelog boksita u bijelim rudinama (Zapadna Crna Gora). First Coll. on Geol. of Dinaric Alps, Ljubljana.

Reiss, Z., 1957. Occurrence of Nezzazata in Israel. Micropaleontol. Vol. 3, No. 3 .

1961. Lower Cretaceous microfacies and microfossils from Galilee. Bull. Research Council Israel, sect. G, No. 16, Oil Div., Paper No. 3.

Renz, C., 1928. Die Verbreitung kretazischer Foraminiferen in der westgriechischen Olonos-Pindoszone. Prakt. Acad. d'Athènes. Vol. 3.

1930a. Geologische Reisen im griechischen Pindosgebirge (1929). Eclog. Geol. Helv. Vol. 23, No. 1.

, 1930b. Geologische Voruntersuchungen auf Kreta. Prakt. Acad. d'Athènes. Vol. 5.

1936. Neue Beiträge zur Geologie der Insel Leukas und ihrer Umgebung (Westgriechenland). Eclog. Geol. Helv. Vol. 29, No. 2.

1947. Progress of the geological exploration of Greece. Am. J. Sci. Vol. 245.

1955. Die vorneogene Stratigraphie der normalsedimentären Formationen Griechenlands. Inst. f. Geol and Subsurface Research, Athens.

Renz, C., and Mistardis, G., 1939. Der Nachweis von Orbitolinenkalk in Aegaleos. Prakt. Acad. d'Athènes. Vol. 14.

Renz, C. and Riechel, M., 1946. Beiträge zur Stratigraphie und Paläontologie des ostmediterranen Jungpaläozoikums und dessen Einordnung im griechischen Gebirgssystem. Eclog. Geol. Helv. Vol. 38, No. 2.

, 1949a. Kreideforaminiferen aus dem Kalkhügel von Eleusis (Attika). Eclog. Geol. Helv. Vol. 41, No. 2. ,1946b. Neue Foraminiferenfunde im boeotischen Seengebiet (mittelgriechenland). Eclog. Geol. Helv. Vol. 41, No. 2.

, 1950. Neue Fossilfunde in Griechenland und Vorderasein. Eclog. Geol. Helv. Vol. 42, No. 2.

Sartoni, S. and Crescenti, U., 1962. Ricerche biostratigrafiche nel Mesozoico dell' Appennino meridionale. Giornale di Geol., Ann. Museo Geol. Bologna. ser. 2, Vol. XXIX (1960-1961).

Sartoni. S. and Colalongo, M. L., 1964. Sul Cretaceo dei dintorni de Caiazzo (Caserta). Mem. Soc. Geol. Ital. Vol. IV.

Schroeder, R., 1963. Palorbitolina, ein neues Subgenus der Gattung Orbitolina (Foram.). Neuses Jahrb. Geol., Pal. Abhandl. Vol. 117 (Festband Lotze). , 1964. Orbitoliniden-Biostratigraphie des Urgons nordöstlich von Teruel (Spanien). Neuses Jahrb. Geol. Pal. Abhandl., Monatshefte, No. 8. 
Sinni Luperto, E., 1966a. Microfaune mesozoiche del M. Raparo. Boll. Soc. dei Naturalisti in Napoli. Vol. LXXV-1966.

1966b. Microfaune del Cretaceo delle Murge Baresi. Geol. Romana. Vol. V.
Smout, A. H., 1956. Three new Cretaceous genera of foraminifera related to the Ceratobuliminidae. Micropaleontol. Vol. 2, No. 4. 


\section{PLATE 1}

(Scale bars represent 1 millimeter.)

Figure 1

Figure 2

Figure 3

Figure 4

Figures 5-6
Fractured dolomite, barren. Hole 127, Core 16, piece 1.

Fractured dolomitic limestone. Hole 127, Core 17, piece 2.

Dolomitized limestone with Orbitolina. Hole 127, Core 17 , piece 3 .

Fractured dolomitized limestone with Chrysalidina. Hole 127 , Core 17 , piece 8 .

Fractured dolomitized limestone with Orbitolina. Hole 127 , Core 17 , piece 8 . 
PLATE 1
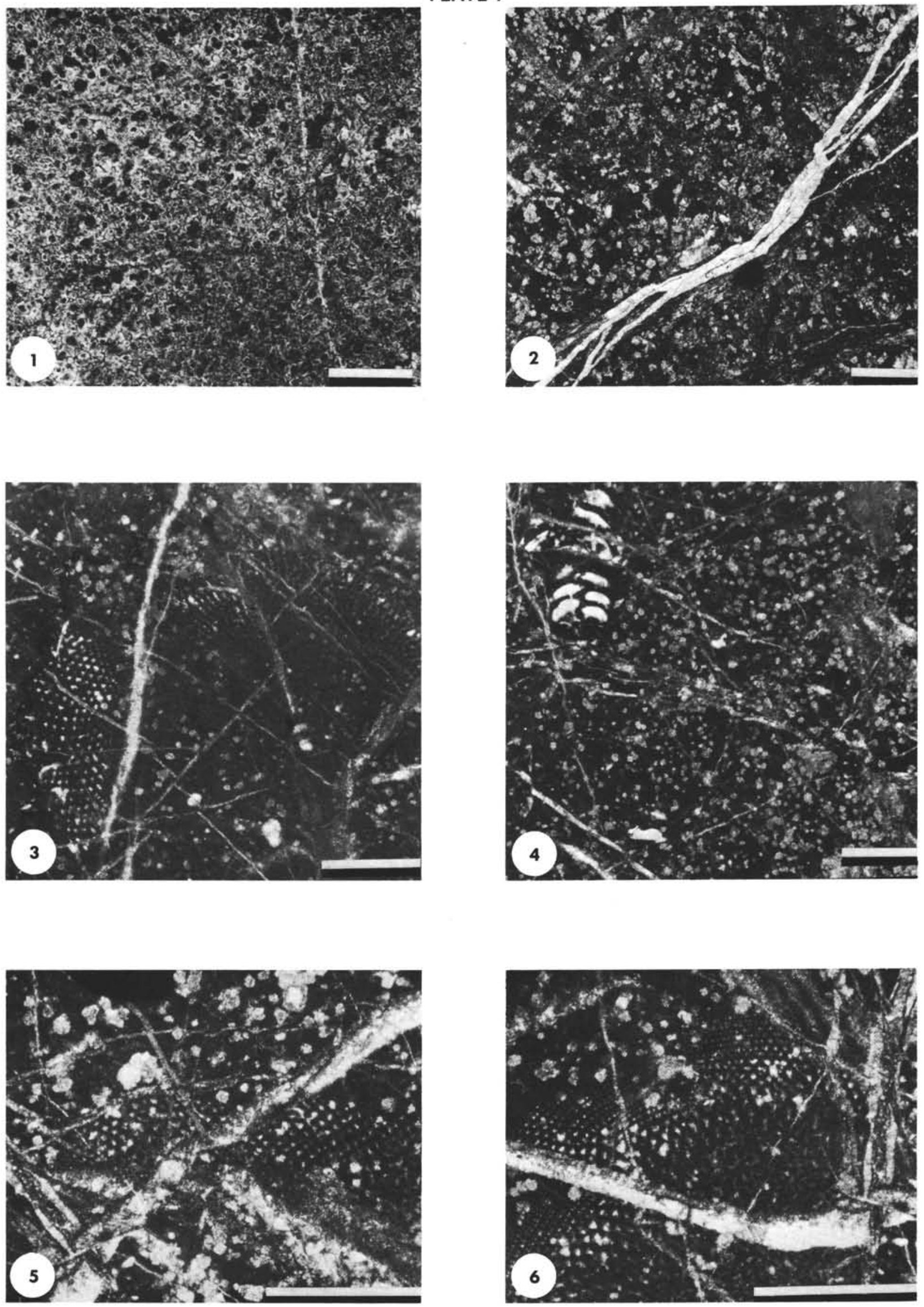


\section{PLATE 2}

(Scale bars represent 1 millimeter except for Figure 4, where it represents 0.1 millimeter.)

Figures 1,2 Micritic limestone with Cuneolina cf. laurentii Sart. \& Cresc., (Cu) Sabaudia minuta (Hofker) (S) Haplophragmoides? sp. (H). Hole 127, Core 18, piece 4.

Figure 3 Fractured limestone as above with Sabaudia minuta (Hofker) or Cuneolina and Ophtalmidiidae. Hole 127, Core 18 , piece 4.

Figure 4 Limestone as above, with Sabaudia minuta (Hofker), transverse section. Hole 127, Core 18, piece 4 .

Figures 5,6 Limestone as above, with Hensonella cylindrica Elliot. Hole 127, Core 18, piece 4. 
Plate 2
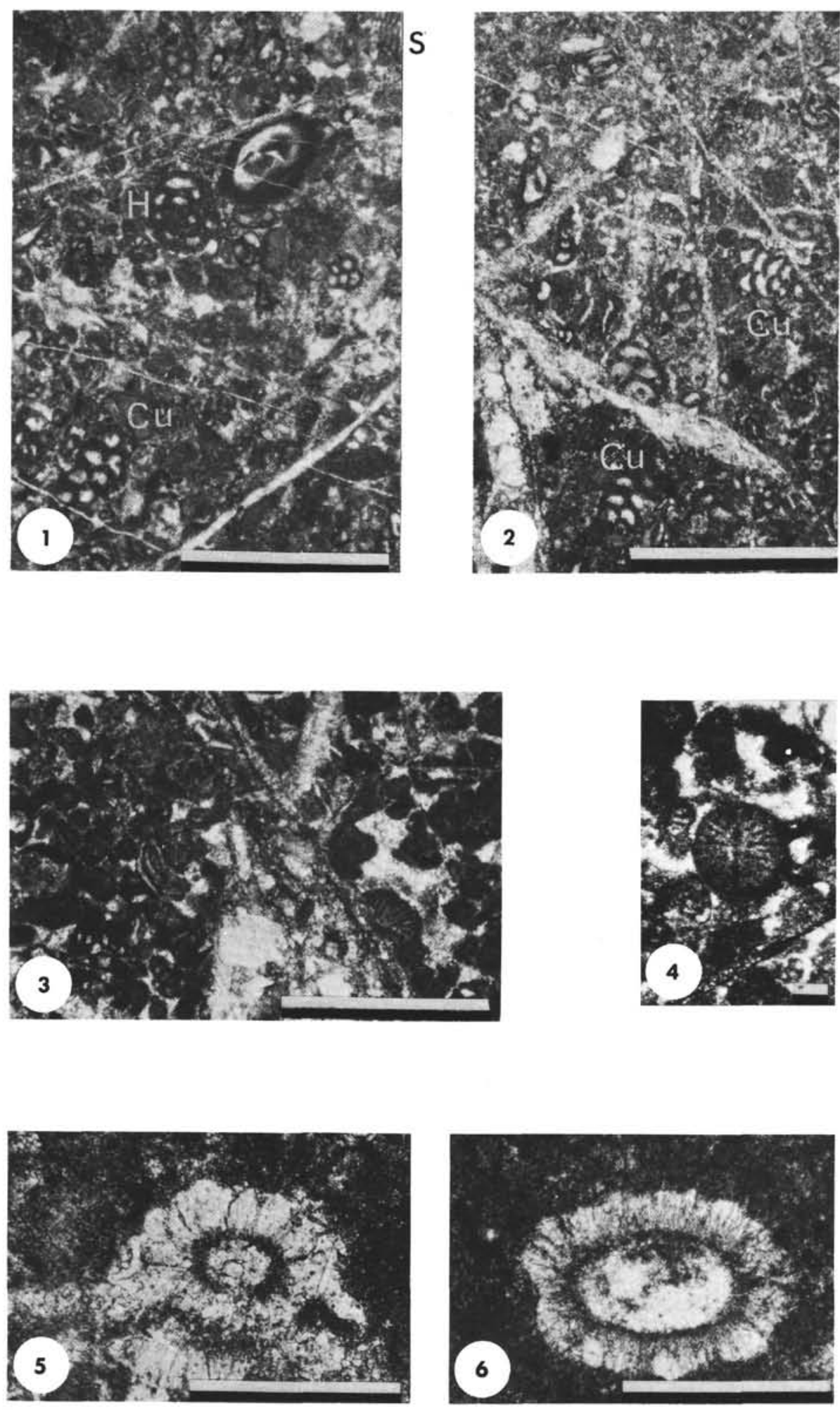
PLATE 3

(Scale bars represent 1 millimeter.)

Figure 1 Micritic limestone with Chrysalidina (Ch) Valvulammina aff. picardi Henson (V). Hole 127, Core 18, piece 4.

Figures 2,3 Limestone as above with Chrysalidina. Hole 127, Core 18 , piece 4.

Figure 4 Limestone as above, with Valvulammina aff. picardi Henson. Hole 127, Core 18, piece 4. 
PLATE 3
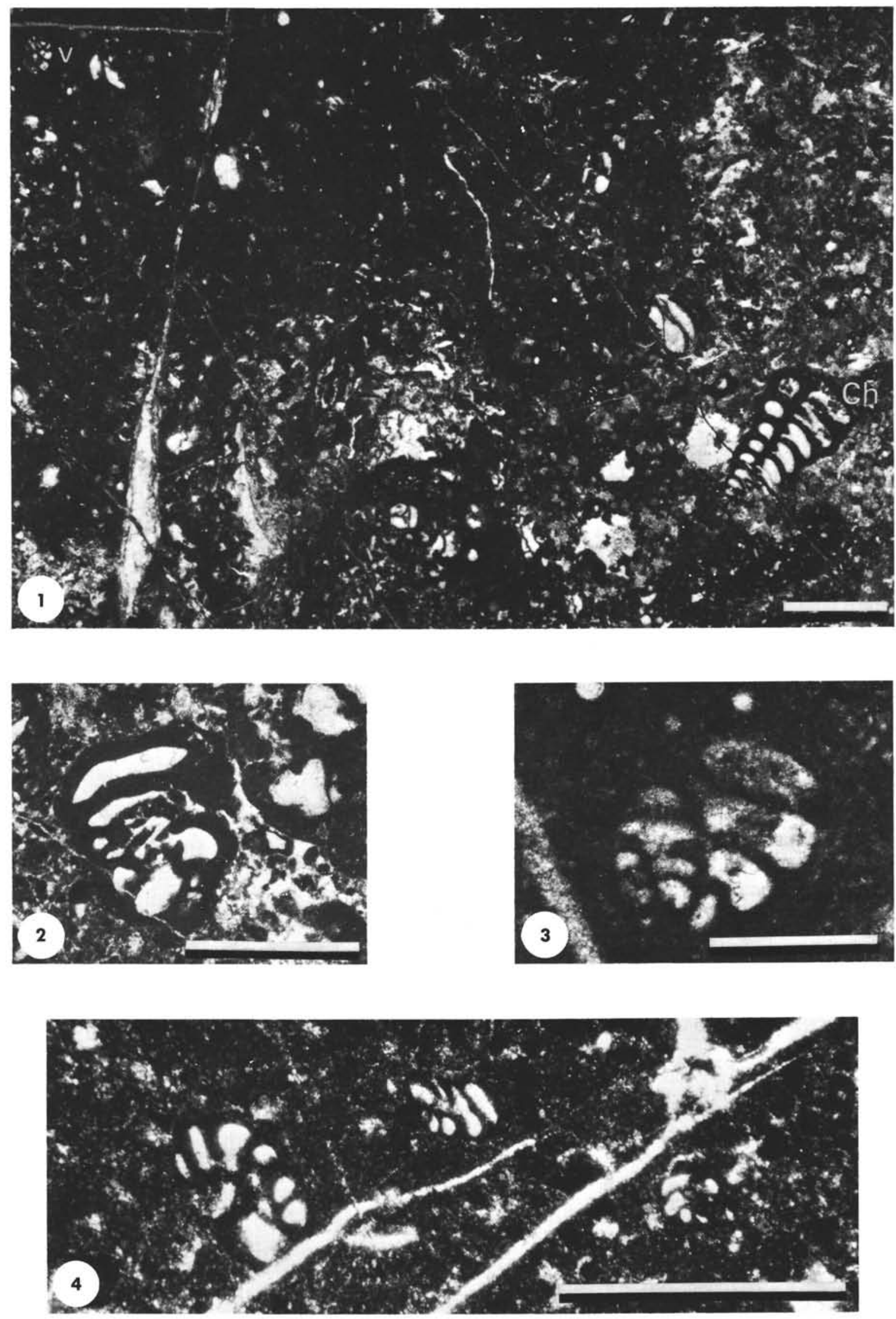
PLATE 4

(Scale bars represent 1 millimeter.)

Figure 1 Micritic limestone with Chrysalidina (Ch) Nezzazata gr. simplex Omara (N) Bacinella irregularis Radoicic (Ba) Boueina? (B). Hole 127A, Core 4.

Figure 2 Limestone as above, with Orbitolina. Hole 127A, Core 4.

Figure 3 Limestone as above, with Chrysalidina. Hole 127A, Core 4.

Figure 4 Limestone as above, with Hensonella cylindrica Elliot. Hole 127A, Core 4. 
PLATE 4
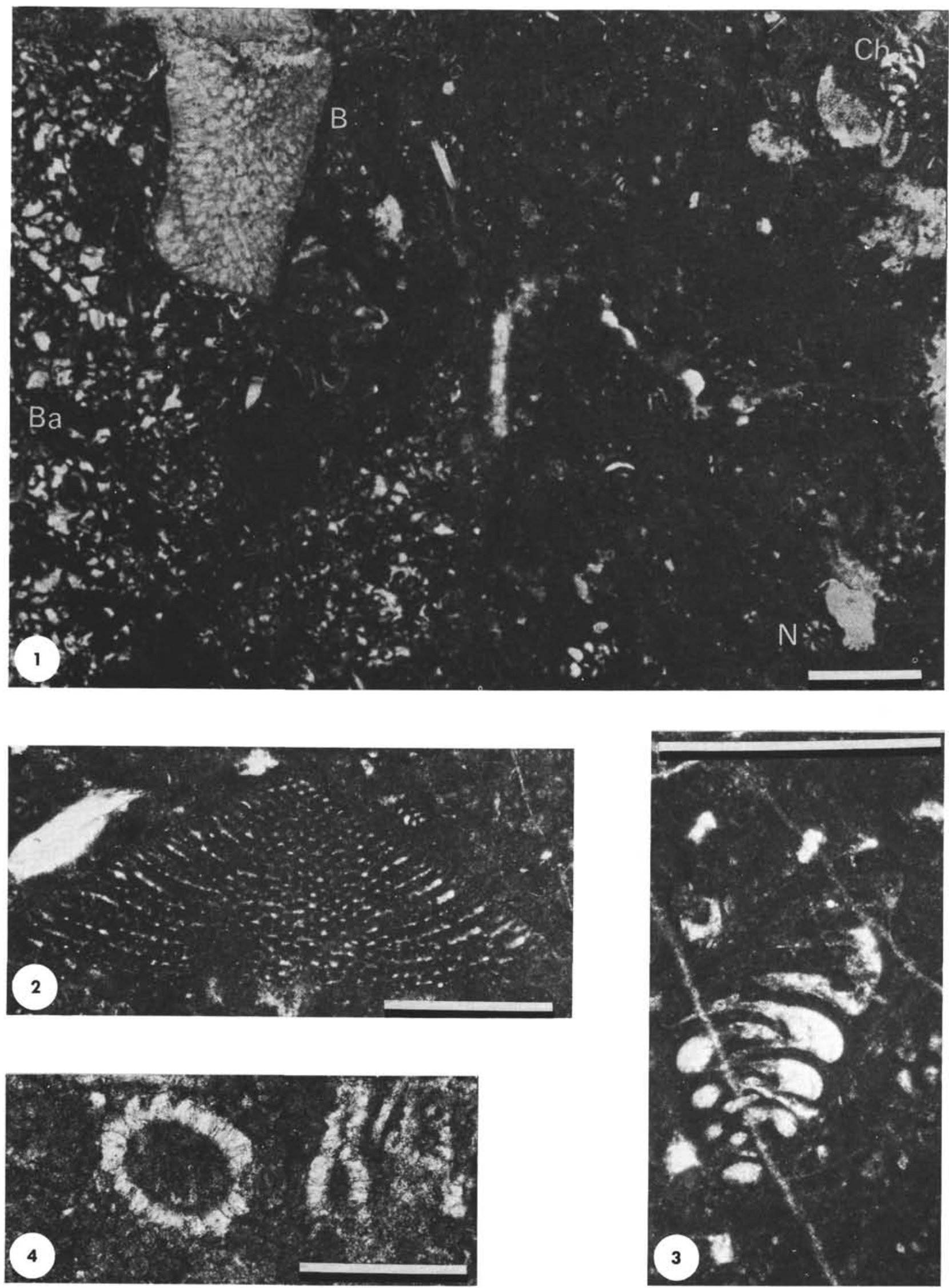


\section{PLATE 5}

(Scale bars represent 1 millimeter.)

Figure $1 \quad$ Micritic limestone with Orbitolina (O) Chrysalidina (Ch). Hole 127A, 4-CC.

Figure 2 Biomicritic limestone with Orbitolina (O) Cuneolina cf. laurentii Sart. \& Cresc. (Cu) Miliolidae. Hole 127A, Core 5, piece 2. (part of Figure 3).

Figure 3 As above with Orbitolina (O) Cuneolina etc. Hole $127 \mathrm{~A}$, Core 5 , piece 2.

Figure 4 Limestone as above with Valvulammina aff. picardi Henson. Hole 127A, Core 5, piece 2.

Figure 5 Limestone as above with Sabaudia minuta (Hofker). Hole 127A, Core 5, piece 2. 


\section{PLATE 5}
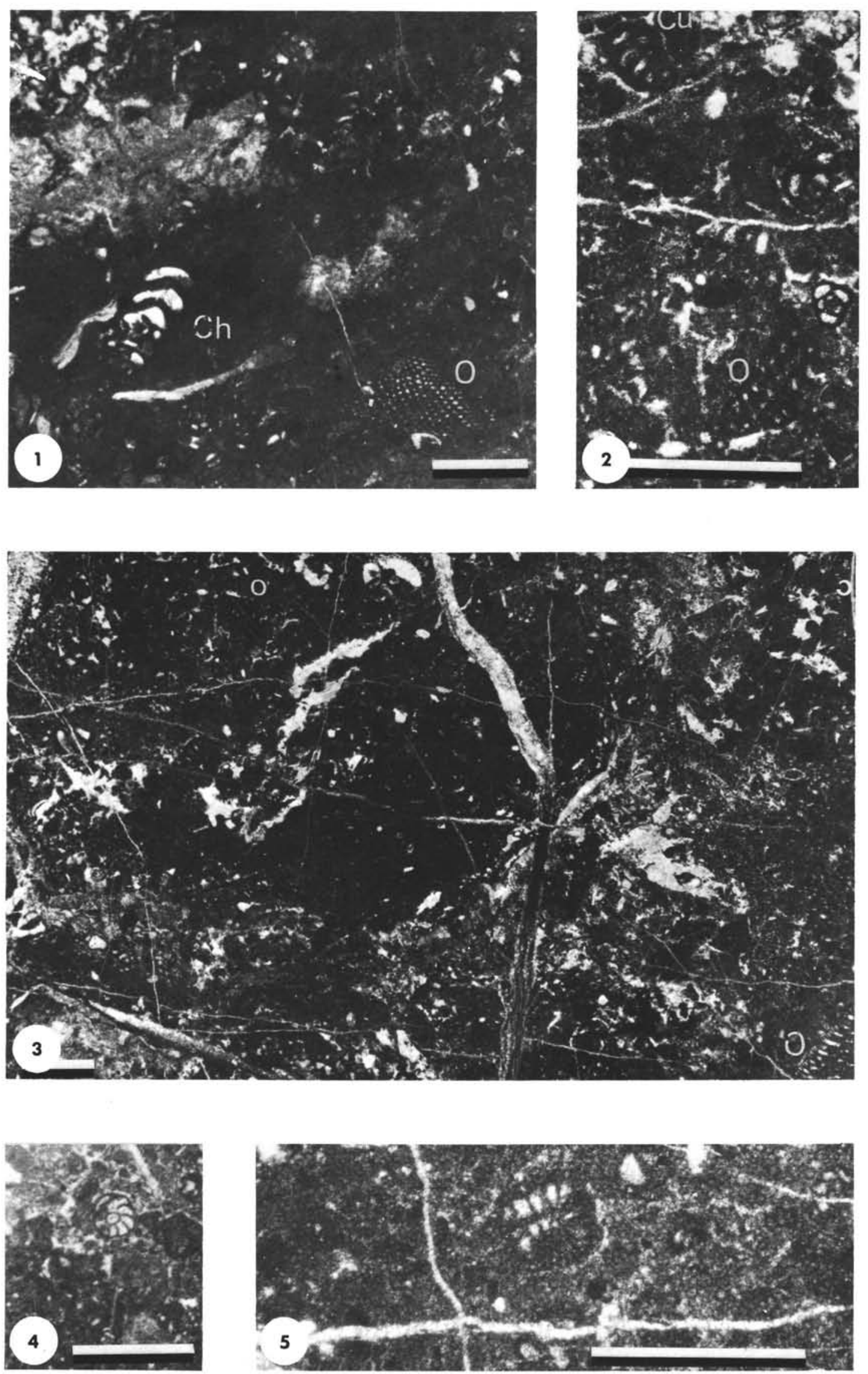


\section{PLATE 6}

(Scale bars represent 1 millimeter.)

Figure 1

Figure 2

Figures 3-6
Biomicrite with Nezzazata gr. simplex Omara. Hole $127 \mathrm{~A}$, Core 5 , piece 2 .

Limestone as above with Valvulammina aff. picardi Henson. Hole 127A, Core 5, piece 2.

Limestone as above with Orbitolina. Hole 127A, Core 5 , piece 2 . 
PLATE 6
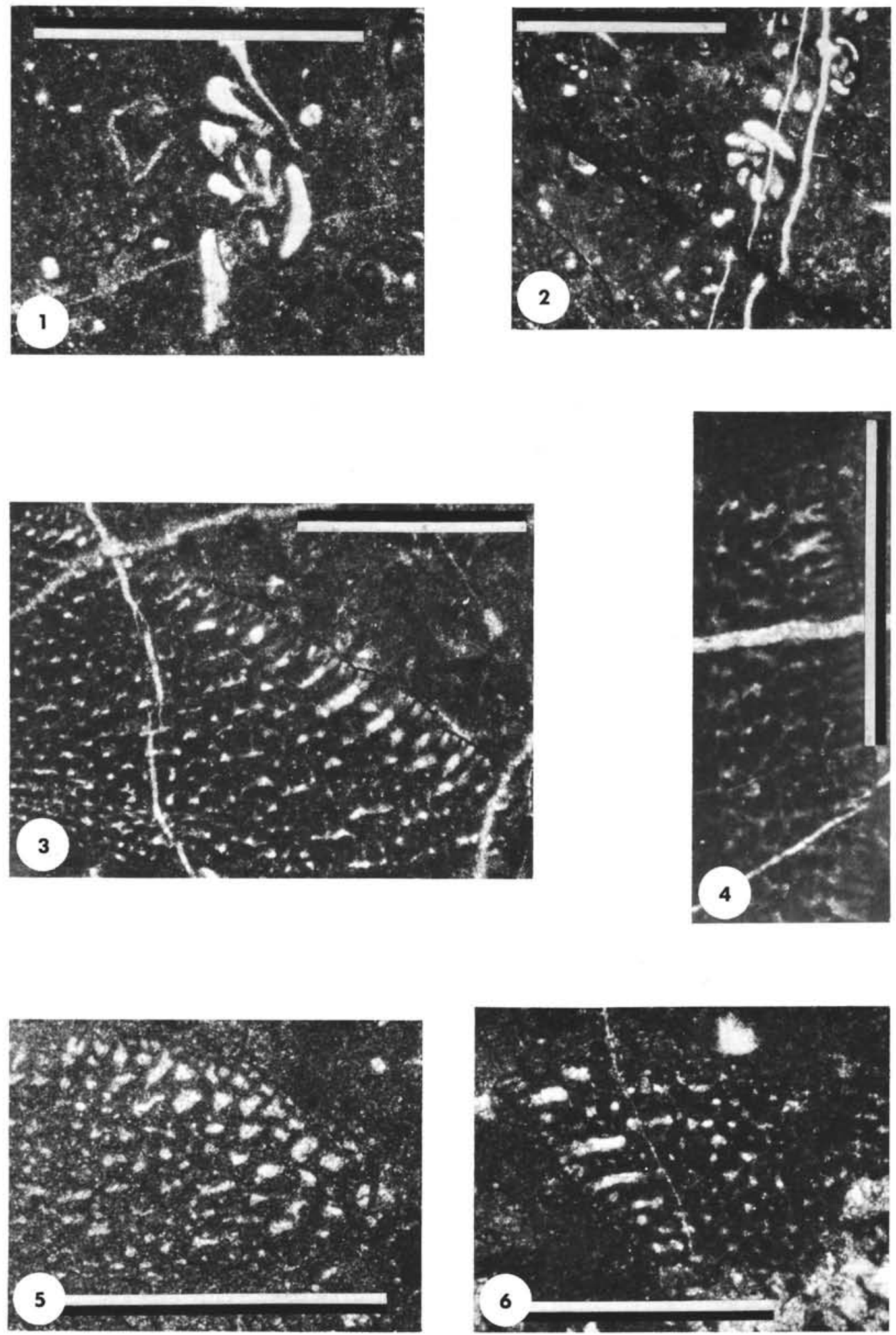


\section{PLATE 7}

(Scale bars represent 1 millimeter.)

Figure 1

Figure 2

Figure 3
Pebble of Cretaceous biomicrite embedded in Orbulina-Globigerina marl. Hole 127B, Core 1, piece 1.

Limestone pebble as above with Valvulammina aff. picardi Henson. Hole 127B, Core 1, piece 1.

Limestone pebble in Orbulina-Globigerina ooze as above. Hole 127B, Core 1, piece 1 . 
PLATE 7
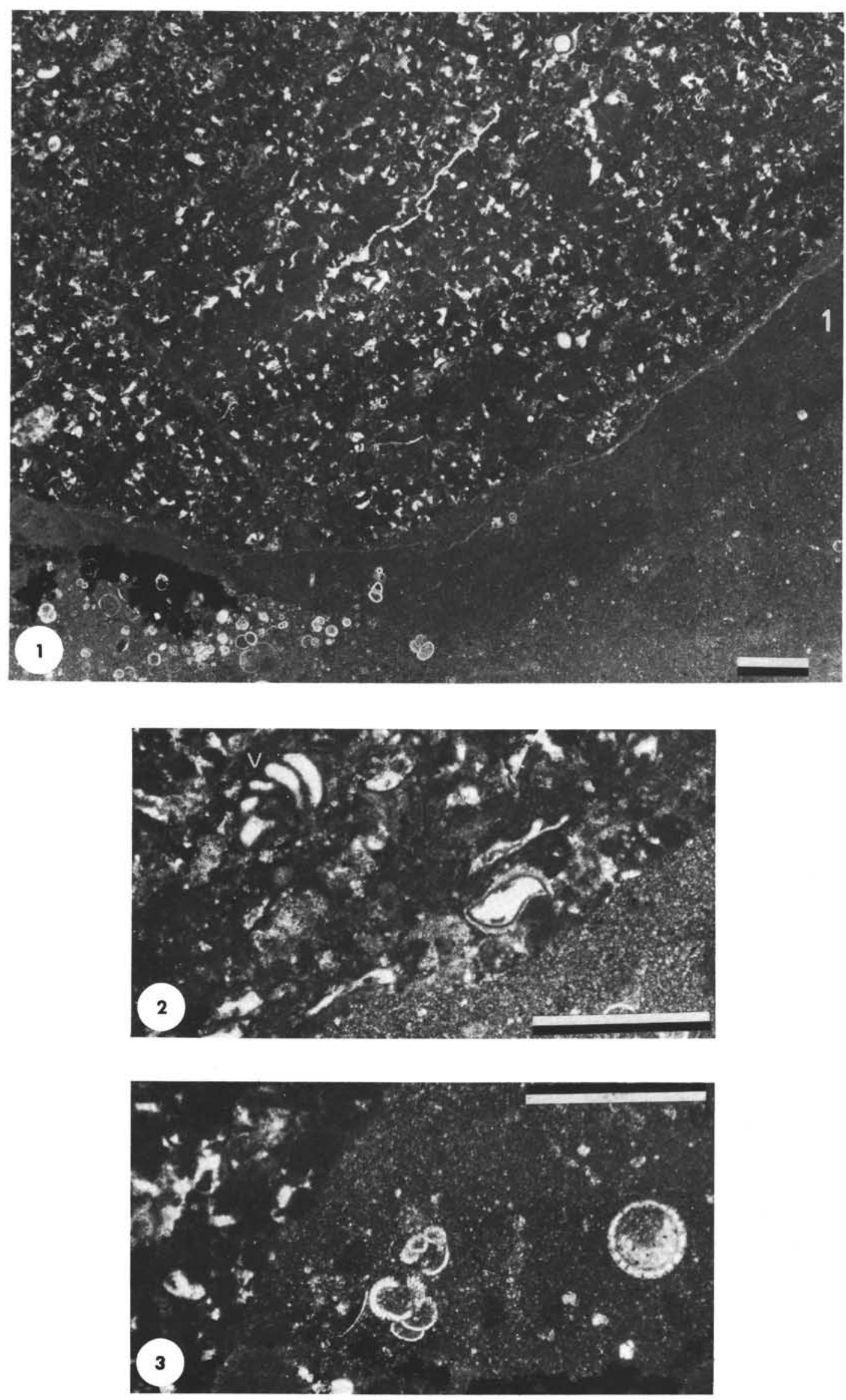


\section{PLATE 8}

(Scale bars represent 1 millimeter.)

Figures 1-3 Orbitolina-bearing micrite. Hole 127B, Core 1, piece 2.

Figure 4 Angular fragments of fractured dolomite and dolomitic limestone, components of a breccia with a matrix of Orbulina-Globigerina marl. Hole 127B, Core 1 , piece 3 . 
PLATE 8
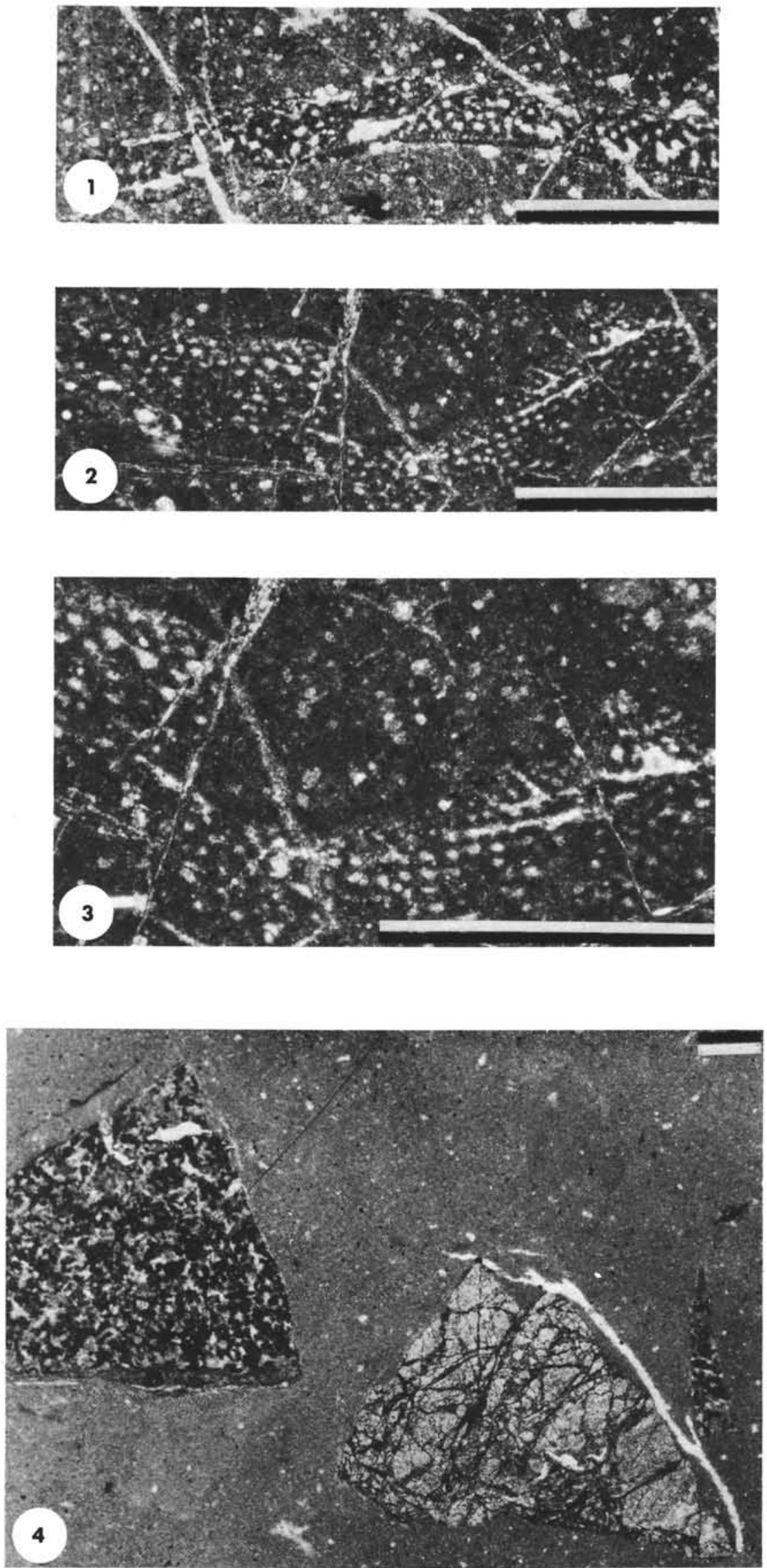